\title{
The Relationship between Job Stress and Front-liners' Job Performance in a Shared Service Center in Malaysia
}

\author{
Farah Syazreena Azmi, Siti Asiah Md. Shahid, and Anisah Alwi
}

\begin{abstract}
The purpose of this study is to examine the relationship between job stress and job performance of front-liners in a shared service center, Malaysia. The conceptual framework of this study is based on the model of Job Stress (role ambiguity, role conflict, inadequate resources, and workload) and the concept of job performance. A total of 113 front-liners from various departments in a shared service center were selected as respondents through convenience sampling technique. Findings indicated that job stress was significantly related to job performance.
\end{abstract}

Index Terms - Job stress, job performance, front-liners, shared service center.

\section{INTRODUCTION}

Problems in organizations are seen as the most dangerous cause of stress at work over the past few decades. Stress issue becomes a phenomenon at many organizations especially in service organizations since the nature of the work itself requires employees to face various types of customer's behaviour. As mentioned by [1] force, pressure, or tension subjected upon an individual who fights these forces and try to sustain its real state is defined as stress.

In organizational outlook, shared service center organization may lose valuable front-liners through turnover brought on by anxiety, pressure, emotional exhaustion, and/or physical implications such as hypertension and ulcers as a direct result of unregulated job stress [2]. Hence, it is crucial for front-liners to be alert in allowing emotionally-based behaviour to be part of the service delivery encounter. It is critical to recognize causes of job stress and how front-liners can most effectively manage the resultant emotions.

\section{LITERATURE REVIEW}

Although researchers have given the issue of job stress a great deal of attention and practitioners have attempted to reduce the influences of the sources of job stress, to date job stress continues to be problematic. Today, front-liners have one of the ten most stressful jobs in the United States, [3] demonstrated that sources of job stress and reactions to job stress differ across job levels and types of employment.

Manuscript received November 25, 2014; revised March 6, 2015.

Farah Syazreena Azmi and Anisah Alwi are with the Faculty of Business Management, University Technology Mara Puncak Alam, 42300 Puncak Alam, Selangor, Malaysia (e-mail: farah2070@salam.uitm.edu.my, anisah@puncakalam.uitm.edu.my).

Siti Asiah Md. Shahid is with the Institute of Business Excellence, University Technology MARA Shah Alam, 40450 Shah Alam, Selangor Darul Ehsan, Malaysia (e-mail: sitia348@puncakalam.uitm.edu.my).
Therefore, one possible explanation as to why job stress continues to be problematic is due to relevant sources of job stress for front-liners have not been identified. Job stress experienced by front-liners could reduce their job performance, therefore this study focuses specifically in one shared service center which has not been addressed seriously.

Job stress was first conceptualized in 1964 by [4] whereby job stress is viewed as dysfunctional for organizations and their members even though stress has been variously viewed as an ecological stimulus to an individual. In other opinion by [5], in a recent meta-analysis, $24(46 \%)$ of the 52 empirical studies examine, supported a negative linear relationship between job stress and job performance. In contrast, the U-shaped/curvilinear relationship between job stress and performance can be originally traced back to the work of Yerkes and Dodson [6]. This issue has been widely discussed for many years by many researchers. According to [7] there is an inverse relationship between job stress and job performance indicating that there is high job stress in the house officers, resulting in low job performance. They identified six dimensions of job stress which are job pressure, job description conflict, lack of communication and comfort with supervisor, job related health concern, work overload, and lack of resources.

In 2001, [8] develop another theory of job stress which consists of job-related stress of organizational aspects, such as long work hours, lack of organizational support and organizational change. Generally, job stress is vital for front-liners because in their everyday work they deal with people with various emotion related to product or services offered.

Background of this study is based on the concept of job stress by [9]. According to them job stress consists of role ambiguity, role conflict, inadequate resources and workload. Indeed, [10] found role ambiguity to be a significant source of job stress that has an indirect negative influence on service delivery (job performance) of front-liners (both nonprofessional service providers and higher-level service providers). However, some studies propose this relationship does not exist for other job types, such as clerical workers, police sergeants, and university professors [3], and [11]. These inconsistent findings suggest that role ambiguity may be a function of job type and may not be typical to all organizations. For example, [3] measured sources of job stress by asking respondents from three occupations to describe a concrete event that he or she perceives to be stressful which occurred at work in the month prior to the study. He also asked respondents how stressful the event was (not very to very much) and why the incident is perceived to be a problem for them and to report their accompanying emotional reaction to the incident. He concluded that, role ambiguity is rarely identified as a source of job stress across 
three occupations.

In a study of salespeople representing various industries, [12] found that role conflict was negatively linked to customer-oriented selling, a trait associated with increased job performance. Moreover, employees facing role conflict may experience emotional extraction from the job leading to reduced job performance [10]. Consequences of studies exploring the effects of role conflict on job performance, however, have been inconsistent. For example, some researchers [13] found that role conflict had a negative effect on job performance, and others [14] observed that role conflict created a positive effect on job performance. In fact, [15] in his study towards salesperson, suggested that modest levels of role conflict might encourage some people to sell and, thus, increase their job performance. Still, most researchers agree that extreme role conflict erodes job performance [16].

In addition, workload stress can be defined as reluctance to come to work and a feeling of constant pressure (i.e. no effort is enough) accompanied by the general physiological, psychological, and behavioural stress symptoms [17]. Furthermore, work overload both quantitatively and qualitatively has been empirically linked to a variety of physiological, psychological, and behavioural strain symptoms [18].

Other than that, situational constraints include stressors such as lack of necessary information, problems with machines and supplies as well as stressors within the work environment. Situational constraints are assumed to impair job performance directly. For example, when a machine breaks down one cannot continue to accomplish the task and therefore performance will suffer immediately. Moreover, situational constraints, as other stressors, can have an indirect effect on performance by requiring additional regulation capacity as mention by [19].

Moreover, the essence of job performance relies on "the demands of the job, the goals and missions of the organization, and beliefs in the organization about which behaviours are most valued" [20]. However, based on [9] job performance is the result of three factors working together: skill, effort, and the nature of work conditions. Skills include knowledge, abilities, and competencies the employee brings to the job; effort is the degree of motivation the employee puts forth toward getting the job done; and the nature of work conditions is the degree of accommodation of these conditions in facilitating the employee's productivity. In contrast, according to [6], job performance can be viewed as an activity in which an individual is able to accomplish the assigned task successfully, subject to the normal constraints of the reasonable utilization of available resources.

\section{RESEARCH OBJECTIVE}

The objective of this study is to determine whether there is a significant relationship between job stress and job performance in the model

\section{Methodology}

This study used a survey research design. Survey questionnaires were used to collect data from the respondents comprising of front-liners at a shared service center.

There were 31 questions (including demographic items) in this questionnaire. A 26-item survey was designed to obtain information about the front-liners perceptions on job stress and job performance while a 5-item question was designed to obtain information about the demographics (gender, age, level of education, marital status, and length of service) of the sample. To assess the front-liners' job stress, a series of questions developed by [9] was utilized. In addition, job performance was measured using the self-evaluation adapted from [21].

A total of 132 questionnaires were distributed to front-liners in shared service center which offer solutions ranging from day-to-day back office operations to provision of consultancy, and management decision support services and 113 responded (85.61 percent).

\section{RESULTS}

\section{A. Sample Description}

The data of the completed questionnaire were analyzed using SPSS version 20. Respondents of this study consisted of front-liners from a shared service center. With regard to gender, out of 84 responses, $40.5 \%$ of the respondents were male and $59.5 \%$ were female. Examining the respondents' age, $71.4 \%$ of the respondents were in the range of $21-30$ years old, followed by age group between 31-40 years old, while only $2.4 \%$ respondents are below 21 years old. Meanwhile for level of education, the majority of the respondents' held a bachelor's degree with $65.5 \%$, followed by diploma holder with $17.9 \%$ and $7.1 \%$ of with SPM certificate. In addition, 59.5\% respondents work less than four years, followed with $28.6 \%$ who worked for four to six years and only $4.8 \%$ served for seven to nine years with the current organization.

\section{B. Relationship between Independent and Dependent Variables}

This section discusses the findings on the correlation between each component of job stress and job performance for a shared service center. As shown in Table I, the interpretation of the correlation coefficients.

TABLE I: PEARSON CORRELATION COEFFICIENT TABLE INTERPRETATION

\begin{tabular}{lll}
\hline \hline Strength of Association & Negative & Positive \\
\hline Weak & -0.29 till -0.10 & 0.10 till 0.29 \\
Moderate & -0.49 till -0.30 & 0.30 till 0.49 \\
Strong & -1.00 till -0.50 & 0.50 till 1.00 \\
\hline \hline
\end{tabular}

Source: Cohen (1988)

\section{Correlation between Each Component of Job Stress and Job Performance}

As shown in Table II the correlation between all components of job stress and job performance was significant $(p<.05)$, moderate to strong and negative (Table I). Results also indicate that job performance was significant, negative, and had a high correlation with role ambiguity $(r=$ -.567; $p<.01$ ); a significant, negative and weak relationship with role conflict $(r=-.188 ; p<.05)$; a significant, negative and strong relationship with inadequate resources $(r=-.406$; 
$p<.01)$; and in contrast, a significant moderate but positive correlation with workload $(r=.319 ; p<.05)$. On the other hand, job performance has a negative moderate correlation with overall job stress $(r=-.325 ; p<.05)$. With regards to this, negative relationships between the three job stress variables, shows that the more the front-liners experience job stress, the less their job performance is and vice versa. In summary, role ambiguity has the strongest association with job performance $(r=-.567 ; \mathrm{p}<.01)$ while role conflict, had the weakest relationship $(r=.188 ; p<.05)$ relationship.

TABLE II: CORRELATION COEFFICIENTS BETWEEN THE FOUR COMPONENTS OF Job STRESS AND Job PERformance

\begin{tabular}{lc}
\hline \hline Components Job Stress & Pearson Correlation Coefficient $(r)$ \\
\hline \hline Role Ambiguity & $-.567^{* *}$ \\
Role Conflict & $-.188^{*}$ \\
Inadequate Resources & $-.406^{* *}$ \\
Workload & $.319^{* * *}$ \\
Overall Job Stress & $-.325^{* *}$ \\
\hline \hline
\end{tabular}

**Significant at .01

*Significant at .05

\section{DISCUSSION}

The results of this study show that the correlation between job performance and role ambiguity for a shared service center was significant, negative, and strong. This is consistent with [22] study but not consistent with [3], and [13] study. This indicates that if front-liners are unclear about their primary role due to lack of requisite information for successful performance of that role, their performance will diminish.

Further, this study reveals that the relationship between job performance and role conflict were significant, negative, and the weakest among all the four components of job stress which is similar with [12] study but not consistent with [16] study. This reveals that there is an incompatibility between management's demands or expectations of the front-liners. With regard to the relationship between job performance and inadequate resources, results indicate that the relationship between the two were significant, negative and high among front-liners in a shared service center. This result is similar to [19]. With regards to this, lack of resources to perform work led to lower job performance among the front-liners. Thus, front-liners should be able to cope with inadequate resources at their workplace which indeed affected their job performance. In contrast, the results of this study also explain that the relationship between job performance and workload was significant, positive, and moderate which is consistent to [11], and [23] study however inconsistent with [24]. Based on the findings, workload is positively associated with job performance, whereby front-liners must maintain their perceptions on workloads that enable them to increase their job performance. Depending on the nature of workload, variations occur in the level of individual performance in such a way that if the workload includes performing of routine tasks then performance is not affected, however if the task difficulty increases, the level of performance significantly decreases [25]. The findings of this study indicate that the role of job stress in front-liners working environment must be further explored. Thus, front-liners need to understand the role of job stress in increasing their job performance and effectiveness at work.

\section{CONCLUSION}

Based on previous researches, there are many contradicts findings on job stress attributes such as role ambiguity, role conflict, inadequate resources, and workloads towards job performance. As extension of previous research, this study revealed role conflict, role ambiguity and inadequate resources was negatively significantly associated with job performance while workloads was found positively significantly related to job performance. In relation to this, it can be concluded that any increases of role ambiguity, role conflict and inadequate resources will lead to lower job performance, thus, as shared service center nature of work that is solely customers oriented, it is agreed by front-liners that these factors lead their lower job performance. Therefore under those circumstances the organization should be aware that these critical factors could lead to lower job performance and eventually will decrease the services quality. Consequently, in relation to job ambiguity and role conflict, employers must address these issues by providing clear job descriptions, job direction, and job expectation from top management. The front-liners must be aware on expectations from top management, the rights, the activities and the responsibilities of his or her position. Additionally, he or she must know what activities will fulfill the responsibility of the position and how those activities are to be performed [26]. Other than informing the employees the expectation and job activities, employers also need to provide them with adequate resources to carry out their duties. As mentioned earlier, front-liners' job requires them to have the ability to control emotion when dealing with challenging customers. Therefore, resources such as accurate information on customers issue should be provided clearly because human regulatory capacity is limited, less capacity is available for accomplishing the task and, as a consequence, performance decreases [27]. Meanwhile, workloads were identified positively associated with job performance. This shows that optimizing the allocation of mental workload to individuals can reduce human errors and lead to increased productivity [28]. On the whole, organization should provide a conducive work environment, which is free from work related stressors with abundant amount of personal and job related resources. The shared service center should formulate policies related to better workplace design and working conditions.

\section{REFERENCES}

[1] U. Bashir and M. I. Ramay, "Impact of stress on employee job performance: A study on banking sector of Pakistan,” International Journal of Marketing Studies, vol. 2, no. 1, 2010.

[2] S. Sauter, L. Murphy, M. Colligan, N. Swanson, J. Hurrell, F. Scharf, R. Sinclair, P. Grubb, L. Goldenhar, T. Alterman, J. Johnston, A. Hamilton, and J. Tisdale. (1999). Stress at Work. [Online]. Available: http://www.cdc/gov/niosh/stesswk.html

[3] L. Narayanan, S. Menon, and P. E. Spector, "Stress in the workplace: A comparison of gender \& occupations," Journal of Organizational Behavior, vol. 20, pp. 63-73, 1999.

[4] R. L. Kahn, D. M. Wolfe, R. P. Quinn, J. D. Snoek, and R. A. Rosenthal, Organizational Stress: Studies in Role Conflict and Ambiguity, New York: Wiley, 1964.

[5] L. A. Muse, S. G. Harris, and H. S. Field, "Has the inverted-u theory of stress \& job performance had a fair test?" Human Performance, vol. 16, pp. 349-364, 2003.

[6] M. Jamal, "Job stress, job performance and organizational commitment in a multinational Company: An empirical study in two countries," 
International Journal of Business and Social Science, vol. 2, no. 20, 2011.

[7] R. Kazmi, S. Amjad, and D. Khan, "Occupational stress and its effect on job performance: A case study of medical house officers of district abbottabad," J Ayub Medical Coll Abbottabad, vol. 20, no. 3, 2008.

[8] J. Davey, P. Obst, and M. Sheehan, "Demographic and workplace characteristics which add to the prediction of stress and job satisfaction within the police workplace," Journal of Police and Criminal Psychology, vol. 16, no. 1, pp. 29-39, 2001.

[9] S. W. Kim, J. L. Price, C. W. Mueller, and T. M. Watson, "The determinants of career intent among physicians at a US air force hospital," Human Relations, vol. 49, pp. 947-76, 1996.

[10] L. A. Bettencourt and S. W. Brown, "Role stressors and customer-oriented boundary-spanning behaviors in service organizations," Journal of the Academy of Marketing Science, vol. 31, pp. 394-408, 2003.

[11] V. B. Lord, "An impact of community policing: Reported stressors, social support and strain among police officers in a changing police department," Journal of Criminal Justice, vol. 24, pp. 503-522, 1996.

[12] T. B. Flaherty, R. Dahlstrom, and S. J. Skinner, "Organizational values and role stress determinants of customer-oriented selling performance," Journal of Personal Selling and Sales Management, vol. 19, no. 2, pp. 1-18, 1999.

[13] S. N. Bhuian, B. Menguc, and R. Borsboom, "Stressors and job outcomes in sales: A triphasic model versus a linear-quadratic-interactive model," Journal of Business Research, vol. 58, pp. 141-150, 2005

[14] B. J. Babin and J. S.Boles, "The effects of perceived co-worker involvement and supervisor support on service provider role stress, performance and job satisfaction," Journal of Retailing, vol. 72, no. 1, pp. 57-75, 1996

[15] J. Singh, "Striking a balance in boundary-spanning positions: An investigation of some unconventional influences of role stressors \& job characteristics on job outcomes of salespeople," Journal of Marketing, vol. 62 , no. 3 , pp. 69-86, 1998 .

[16] J. Singh, J. R. Goolsby, and G. K. Rhoads, "Behavioral \& psychological consequences of boundary spanning burnout for customer service representatives," Journal of Marketing Research, vol. 31, pp. 558-569, 1994.

[17] N. Ahsan, Z. Abdullah, Y. G. F. David, and S. Alam, "A study of job stress on job satisfaction among university staff in Malaysia: Empirical study," European Journal of Social Sciences, vol. 8, no. 1, 2009

[18] T. A. Beehr, J. T. Walsh, and T. D. Taber, "Relationship of job stress to individually and organizationally valued states: High order needs as a moderator," Journal of Applied Psychology, no. 61, pp. 412-447, 1976

[19] S. Sonnentag and M. Frese, "Performance concepts and performance theory," Physchological Management of Individual Performance, John Wiley \& Sons. Ltd, 2002.

[20] N. Befort and K. Hattrup, "Valuing task and contextual performance: Experience, job roles and ratings of the importance of job behaviors," Applied HRM Research, vol. 8, no. 1, pp. 17-32, 2003.

[21] Y. Ouyang, "The mediating effects of job stress and job involvement under job instability: Banking service, personnel of Taiwan as an example," Journal of Money, Investment \& Banking, vol. 11, pp. 16-22, 2009.

[22] M. R. Beauchamp, S. R. Bray, A. Fielding, and M. A. Eys, "A multilevel investigation of the relationship between role ambiguity and role efficacy in sport," Psychology of Sport and Exercise, vol. 6, pp. 289-302, 2004.

[23] C. D. Wicken and J. G. Hollands, "Stress and human error," in Engineering Psychology and Human Performance, 3rd ed. Prentice Hall: Upper Saddle River, NJ, 2000.

[24] R. B. M. Yusoff, A. Khan, M. F. Rasheed, and A. Aamir, "Effects of social support on faculty workload and performance," Review of European Studies, vol. 6, no. 2, pp. 95-103, 2014.

[25] T . O. Gilad, J. Szalma, S. Stafford, and P. Hancock, "The workload and performance relationship in the real world: A study of police officers in a field shooting exercise," International Journal of Occupational Safety and Ergonomics, vol. 14. no. 2, pp. 119-131, 2008 .

[26] Z. Ahmad, "Commitment to independence by internal auditors: The effects of role ambiguity and role conflict," Managerial Auditing Journal, vol. 24, no. 9, pp. 899-892, 2009

[27] N. Moray, "Mental Workload since 1979," International Review of Ergonomics, vol. 2, pp. 123-150, 1988 .

[28] D. Gopher and E . Donchin, "Workload - An examination of the concept," in Handbook of Perception and Human Performance, $\mathrm{K}$
Boff, L. Kaufman, and J. Thomas, Eds., New York: Wiley, vol. 2, pp. 1-49, 1986.

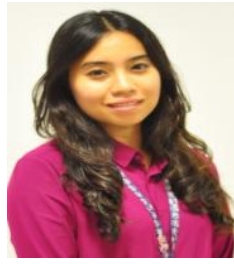

Farah Syazreena Azmi holds a master in office systems management from University Technology Mara Shah Alam, Malaysia in 2012. She also holds a bachelor in office systems management from University Technology Mara Shah Alam, Malaysia, majoring in human resource in 2009. Prior to that she obtained her diploma in office management and technology from Universiti Technology Mara Perak, Malaysia. Currently she is a lecturer at the Faculty of Business Management, University Technology Mara Puncak Alam, Selangor, Malaysia. She has taught several courses in business management including administrative communication for professionals, advanced end user applications, administrative and personnel management, information and communication technologies in organizations and project management. Her current research includes, a study on the influence of job stress and job performance in shared service centre industry in Kuala Lumpur, Malaysia

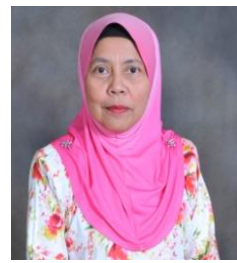

Siti Asiah Md. Shahid obtained a diploma in stenography from Institute Technology Mara, Dungun, Terengganu, Malaysia in 1986. In 1995, she obtained her bachelor of education from the University of Toledo, Toledo, Ohio, USA, majoring in business education. She then pursued her MSc in education in Virginia Polytechnic Institute and State University, Blacksburg, Virginia, USA, in 1997 and graduated as a major in vocational and technical education. Finally she obtained her $\mathrm{PhD}$ in 2011 from University Science Malaysia, Penang, Malaysia, in educational leadership and management. She is a senior lecturer with the Centre of Administration and Management in the Faculty of Business Management, University Technology Mara (UiTM) and currently serves as head of professional and enterprise development, institute of Business Excellence, University Technology Mara Shah Alam, Malaysia She has also served as head of institute education development of this institution. She has taught business management subjects including administrative office management, human resource management, performance management, organizational communication, and organizational behaviour and has served this institution for 28 years. She has written and presented papers on leadership, soft skills, emotional intelligence, and management. Current research includes social support negative affectivity, and work personal life balance of academics. Her research fields include leadership soft skills; Soft skills in higher education; Emotional intelligence; Quality of work life; Organizational behaviour; Business and office management and human resource management. Dr. Siti Asiah Md. Shahid has also participated in innovation, invention, design competition. She leads a project entitled towards a new holistic leadership model and won a gold medal award for her participation. She is a lifetime member of Golden Key National Honor Society, USA, a member of Mara Institute of Technology Academic Staff Association (MITASA), Malaysia and also a member of PEWANI (Women Association Universiti Teknologi Mara).

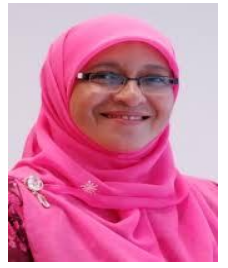

Anisah Alwi holds a master of education degree which was obtained from the University of Nebraska, Lincoln, Nebraska, USA in 1993. She also holds a bachelor of science in education degree from University of Nevada, Reno, Nevada, USA in 1990 and a diploma in stenography from Institut Teknologi Mara in 1980. She is now pursuing her doctoral degree in the Faculty of Business Management, Universiti Teknologi Mara in the area of Leadership Organizational Commitment, Quality Of Worklife and Job Characteristics. She is a senior lecturer with the Centre of Technology Management and Supply Chain in the Faculty of Business Management, Universiti Teknologi Mara (UiTM). She has worked with UiTM for the past 26 years. Prior to teaching in UiTM she worked as a stenographer for four years. In the 26 years working she has co-authored several workbooks (simulation packets) Wajah Ayu Kosmetik - Executive Assistant: An office job simulation; Pyramid holdings Sdn. Bhd. - Administrative assistant: An office job simulation and cyber Jaya college of sciences - Executive officer: An office job simulation. She has also held several administrative posts including examination coordinator and coordinator for out-campus studies and diploma program. She has also conducted short courses in speed writing (shorthand and a malay version of shorthand) and training in personality grooming Ms. Thomas is a life time member of Malaysian English Language Teaching Association (MELTA) and ASIA-TEFL 